\title{
Most-Favored Nation Treatment in Trade Under Central Planning
}

All economic systems have ways in which they determine how much their total trade with the world will be, what commodities will make up that total, and the destinations and sources of those commodities (the geographic composition of exports and imports). In Western economies, which rely heavily on markets, the values of these variables summarize the outcome of a myriad of private decisions, with some influence of governments primarily through tariffs and quotas. In Eastern economies, which rely heavily on central planning, the government itself through its planners directly determines the value of those same variables. ${ }^{1}$

The concept of Most-Favored Nation (MFN) treatment evolved as a mechanism by which governments in market economies could agree mutually to limit interference in private decisions on trade, with the expected consequence being an increase in trade and welfare. When two market economy governments agree to accord MFN treatment to each other's commodities, it means (in its simplest form) that tariffs applied in each country to commodities imported from the other country shall be no higher than the lowest tariffs charged on imports of those commodities from any destination. ${ }^{2}$ At present, Western governments almost universally accord MFN treatment in tariffs to each other; hence, for each Western country commodities coming from all other Western countries are charged the lowest tariff possible. In effect, Western governments have given up trying to influence the geographic composition of mutual trade. Private decisionmakers, motivated primarily by economic criteria, are now making those choices. ${ }^{3}$

1. Throughout the paper, the term "Eastern economies" is used to denote East European countries and the Soviet Union, developed countries which rely heavily on central planning to allocate resources. The term "Western economies" refers to developed Western economies which rely heavily on markets in some form to allocate resources.

2. I am concerned in this paper with MFN status in trade matters, which for a market economy means nondiscriminatory tariffs and quotas. MFN status also encompasses other issues-treatment of ships in ports, treatment of nationals, rights to firms to locate offices in the countries, and so on-but I shall not consider them here.

3. Obviously this oversimplifies matters. For example, despite the fact that the United States accords MFN status to Japanese commodities, still we seek through other devices, such as bilateral negotiations, to control imports from Japan. At present, however, this type of behavior is an exception to the rule and MFN treatment means just that for the majority of commodities moving in international trade.

An earlier version of this paper was presented at the "Conference on U.S.-Soviet Relations in the 1970's," sponsored by the Research and Development Committee of the American Association for the Advancement of Slavic Studies, and held at the Kennan Institute for Advanced Russian Studies in the Smithsonian Institution, Washington, D.C., February 23-25, 1977. I wish to thank Lee Williams for his assistance on the research for this paper and Harold Berman, Philip Gillette, and Franklyn Holzman for their comments which were very helpful in clearing up many ambiguities in an earlier draft. 
The last major area in which discrimination against imports is clearly evident is East-West trade. The United States still applies discriminatory tariffs to goods from most socialist countries. Western Europe accords MFN treatment in tariffs to most socialist countries, but still retains special quotas on imports from those countries. Thus the issue of MFN treatment constantly arises in East-West trade, primarily as Eastern governments demand nondiscriminatory treatment for their imports and exports. But what, if anything, should Western governments request as compensation for removing discriminatory barriers to trade with the East? MFN treatment in the Eastern tariff system would have little or no meaning because planners control imports, and tariffs do not influence their decisions. If discrimination is practiced by the East at all, it is within the planning process itself, which is not visible to outsiders. Consequently Western governments face a dilemma. Most of the means they use to discriminate against trade with Eastern countries are visible means such as tariffs and quotas. Eastern countries, however, appear to have invisible means which they can employ to discriminate against particular partners or against groups of partners (for example, West against East), and Western governments would find it almost impossible to specify a visible quid pro quo within the planning process for the removal of discriminatory barriers to trade with Eastern countries.

Historically, negotiations on these issues between Eastern and Western countries have reached two types of solutions: (1) Mutual grants of MFN status in tariffs, possibly with declarations that only commercial considerations will influence import decisions on both sides; and (2) Western government grants of MFN status and Eastern government agreements to quotas of some type on the value of imports from the Western partner. ${ }^{4}$ The first solution implies that there is no tangible way Eastern countries can reciprocate a grant of MFN status from a Western country, hence the Western country settles for an exchange of substance for form. This solution ignores the different roles tariffs play in the two types of systems, and it has a long history which goes back to some of the first trade agreements the Russians signed with the Baltic countries in the $1920 \mathrm{~s}^{5}$ Its strongest advocate today seems to be the Soviet Union, which has a two-column tariff, with higher rates for retaliation against those who do not give MFN status to Soviet goods. In negotiations on MFN status they can therefore offer MFN tariffs on imports from the market economy with which they are negotiating. In the second solution the Western government recognizes the different role tariffs play in the two systems and seeks guarantees from the Eastern economy in exchange for granting MFN status. This solution also has a long history, beginning with agreements in the late twenties between the Soviet Union and Latvia

There are also exceptions to MFN treatment. Countries which belong to economic unions (such as the European Economic Community) may apply tariff rates below MFN rates in their mutual trade, and developed countries have agreed among themselves to apply what are called "Generalized Preferences" to imports from developing countries in the form of tariff rates somewhat below MFN rates.

4. I shall not discuss a third solution which seems uniquely American-that of asking concessions in the political system in return for the removal of economic discrimination-because I wish to focus only on reciprocity in the economic sphere. Moreover, I think this solution is doomed to failure.

5. Martin Domke and John Hazard, "State Trading and the Most-Favored-Nation Clause," American Journal of International Law, January 1958, p. 56. 
and Persia, and including the United States in the thirties. ${ }^{8}$ Since the 1940s it has. been discussed as a basis for trade liberalization between an Eastern economy and a group of Western economies, in which case the Eastern government agrees to an import quota on total trade with a group of Western economies in exchange for receiving MFN status. ${ }^{7}$ The first implementation of the proposal in that form was in the agreement on Poland's accession to GATT (General Agreement on Tariffs and Trade), which was signed in $1967 . .^{8}$ In the eight years of negotiations that led to this agreement Poland conceded the need for reciprocity in its plans in exchange for MFN status but sought to retain for itself the right to compensate individually each country that granted MFN status in tariffs and removed discriminatory quotas. This part of the proposal was not agreed to by the GATT Contracting Parties, and Poland, in exchange for a commitment that GATT members would eliminate discriminatory quotas (MFN tariffs are not an issue for European GATT members) at a date to be determined later, eventually committed itself to a 7 percent per annum increase in imports from GATT members as a whole. ${ }^{9}$

In the case of Rumania's 1971 accession to GATT, the commitment was that Rumania's imports from GATT members would rise at least as fast as its total imports. In the most recent case, that of Hungary in 1973, there are no quotas whatsoever, a tribute to the impact of the Hungarian New Economic Mechanism. ${ }^{10}$

All past solutions share the common premise that Western countries cannot specify how Eastern countries should grant MFN status, or at least cannot verify that indeed MFN status has been granted. The next section of this paper argues that Western economists may now know enough-little as that is-about the process by which Eastern countries plan foreign trade to be able to specify what changes in the planning process would constitute the equivalent of a move toward MFN treatment by Eastern governments and to obtain (admittedly incomplete) evidence to verify it. Western governments still may need to rely on the old solution of quotas-for-MFN-rates, however, because Eastern governments will probably not agree to Western suggestions for changes in their planning process. But now Western governments would be doing it not because they cannot conceive of a way to implement and verify MFN treatment under central planning, but because Eastern economies will not agree to these new proposals. The third section of the paper assumes this will be the case and discusses briefly how economists might assist negotiators in estimating the appropriate change in Eastern imports which would compensate for granting MFN status to them. MFN issues can be negotiated at several levels: between one Eastern and one Western country, between one Eastern country and a group of Western countries, or between groups

6. Ibid., pp. 56-57.

7. Alexander Gerschenkron proposed this solution in his Economic Relations with the USSR (New York, 1945) and it was built into the ill-fated draft of an agreement for the International Trade Organization (Domke and Hazard, "State Trading and the MostFavored-Nation Clause," p. 60).

8. For details on this agreement see Andrew Ian Douglass, "East-West Trade: The Accession of Poland to the GATT," Stanford Law Review, 24 (April 1972): 748-64.

9. There were also provisions concerning dumping which I am ignoring here.

10. It may also be a tribute to their negotiators, but I will not go into an analysis of Hungary's membership in this paper. 


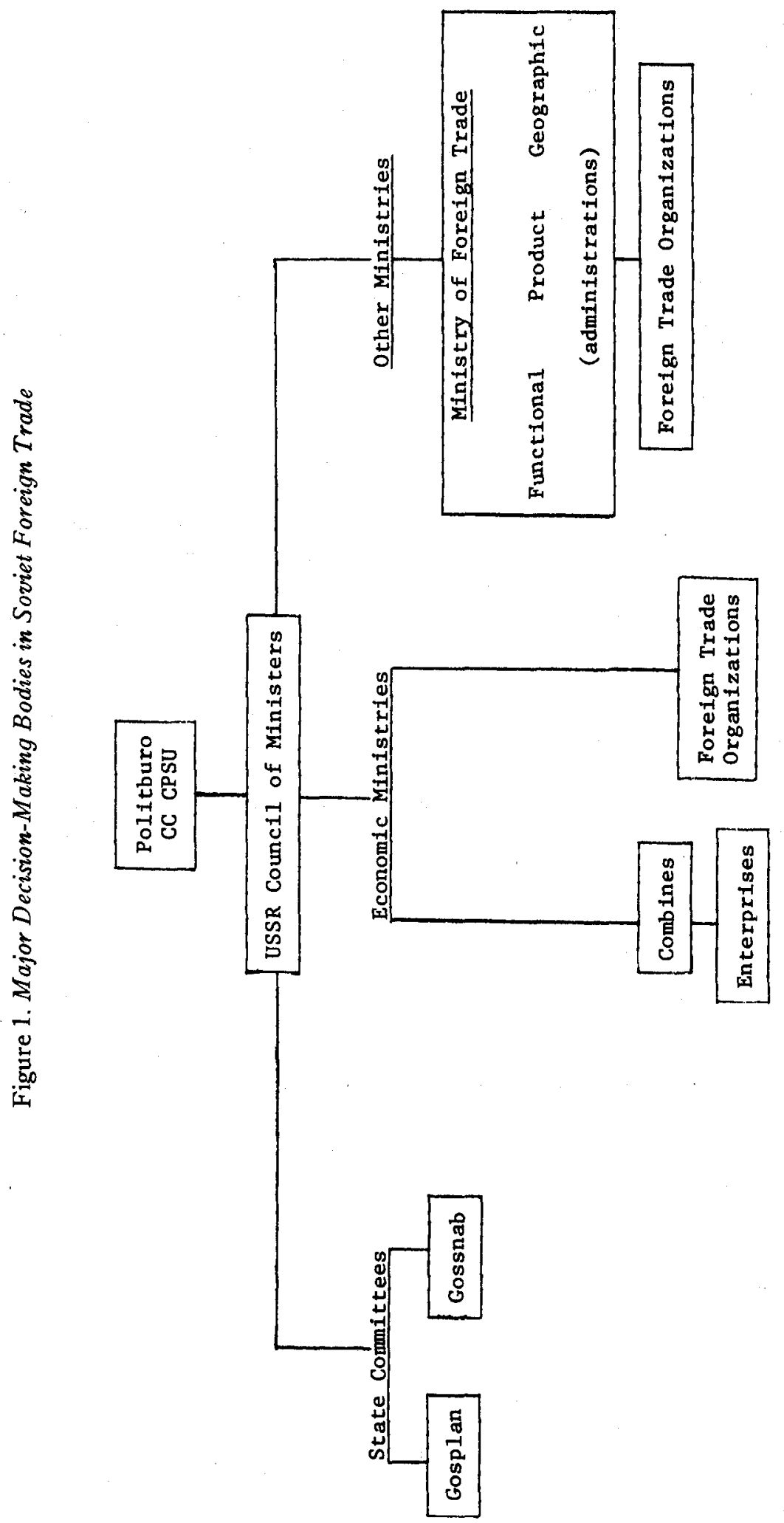


of Eastern and Western countries. ${ }^{11}$ This paper is concerned with issues common to all of those negotiations, rather than the issues particular to each. The final section does, however, discuss briefly the particularly difficult issue of Eastern countries offering MFN status to Western countries as a group-in this situation MFN status is defined in relation to the trading possibilities Eastern countries offer each other.

MFN status is not easy to define operationally for Eastern countries. As a goal, nondiscrimination is applicable to any system ; it simply means that governments shall not encourage discrimination among potential foreign suppliers of products. But Eastern governments own the means of production, decide on the disposition of products, and do not rely primarily on prices to motivate production decisions. Thus tariffs are eliminated as a meaningful vehicle for defining MFN status; however, the possibility of finding other ways to implement the concept of MFN treatment for Eastern economies does exist. The problem is to define the variables which determine decisions on the geographic structure of imports, then to define MFN status by a stipulation that Eastern planners and politicians shall not manipulate those variables to discriminate among countries to which they grant MFN status. In considering the character of such a definition of MFN status for an Eastern economy, it is necessary to look closely at decisions on imports in the particular economy. A simplified model taken from foreign trade decision making in the USSR, which at this level of abstraction is probably a fair example of foreign trade decision making in all Eastern economies except Hungary, will be useful in this examination. ${ }^{\mathbf{1 2}}$

The questions are the same for Eastern foreign trade decision making and for the Western economy: Who makes decisions on imports? What variables influence them in their decisions? What variables can the government use to enforce discrimination? Figure 1 provides a picture of the major organizations involved in foreign trade decisions in the USSR. The Politburo of the Central

11. The first type was common in the 1960 s, but now is less so since the EEC has centralized all negotiations on trade matters. Negotiations between a group of market economies and individual centrally planned economies occurred in the Polish, Rumanian, and Hungarian accessions to GATT, and will most likely continue as other CMEA countries seek to enter GATT (or if Czechoslovakia chooses to reactivate its dormant membership). The groupto-group negotiations may occur as an outcome of the preliminary discussions going on between the CMEA and the EEC concerning their formal relations, or possibly as an outcome of one of the follow-up meetings to the Helsinki CSCE talks.

The fourth logical possibility here, that of individual Western countries negotiating with groups of Eastern countries, does not seem to be very important in relation to the MFN issue. Such cases that do exist-for example, the agreements between the CMEA and Finland, Mexico, and Iraq-are cooperation agreements which do not bear directly on traderelated issues. Trade, in particular trade barriers, is left to bilateral agreements with several East European countries. These agreements set goals for reduction of trade barriers and include clauses on market disruption similar to association agreements EFTA countries have signed with the EEC. The Finnish-East European bilateral agreements call for tariffs going to zero on all save the most sensitive products. No mention is made, other than for Hungary, of how East European countries will reciprocate the tariff reductions; but most likely the Finns will use direct negotiations on the level of trade as they have in the past. For more details, see "Finnország Kereskedelme a szocialista országokkal" [Finland's Trade with the Socialist Countries], Figyelö, August 4, 1976, p. 7.

12. This model is meant to capture the essentials, but not the detail, of Soviet foreign trade decision making. It is based primarily on the overlapping, but also complementary materials in three sources: Harold J. Berman and George L. Bustin, "The Soviet System 
Committee of the Communist Party of the Soviet Union is the de facto supreme organ in the Soviet planning process; with rare exceptions its role involves strategic rather than tactical issues, broad policy rather than specific details. The Council of Ministers is legally the supreme economic authority in the country; again its role is that of broad policy, but it is subordinate to the Politburo. Gosplan, a ministerial-level committee in the Council of Ministers, is in charge of constructing plans and overseeing their execution. Of particular interest are the economic ministries (about fifty), which control domestic production for specific product groups; the functional ministries (only the Ministry of Foreign Trade is shown here); and the committees with ministerial status (Gosplan and Gossnab, the State Committee for Material and Technical Supply).

As might be expected, the Ministry of Foreign Trade itself is a rather complex organization. The directorates (upravleniia) fall into three categories: six which are concerned with geographic areas (Asian Socialist Countries, European Socialist Countries, Western Europe, North and South America, Southeast Asia and the Middle East, and Africa); twelve which deal with functional areas (the most important are Planning and Economic Matters, and Treaties and Legal Matters) ; and seven product directorates (Export of Primary Products; Export of Industrial Equipment; Export of Transport, Road Construction, and Agricultural Machinery; Export of Ready-Made Products and Consumer Goods; Import of Industrial Raw Materials, Food, and Ready-Made Products; Import of Machinery and Equipment from Capitalist Countries; and Import of Machinery and Equipment from Socialist Countries). ${ }^{13}$

The Ministry of Foreign Trade is the major institutional administrator of the state monopoly on foreign trade. Actual foreign transactions are managed by Foreign Trade Organizations (FTO's), ${ }^{14}$ the majority of which are subordinate to the Ministry of Foreign Trade, and the remainder of which are distributed throughout other ministries and some state committees. ${ }^{15}$ The FTO's are, with few exceptions, the only organizations allowed to engage in foreign

of Foreign Trade," Law and Policy of International Business, 7 (Fall 1975): 987-1056; V. P. Gruzinov, Upravlenie mneshnei torgovlei [The Management of Foreign Trade] (Moscow, 1975), chapters 1-3; and John Quigley, The Sovict Foreign Trade Monopoly: Institutions and Laze's (Columbus: Ohio State University Press, 1974), chapters 3, 5, and 6.

13. This is based on Gruzinov, Upravlenic encshnei torgovlei, pp. 70-78; but a similar discussion is found in Quigley, The Sovict Forcign Trade Monopoly, pp. 84-85. I ignore the distinction between administrations and main (glavnye) administrations because it is of no importance for the subject matter of this paper.

14. The Russian word is $o b^{\prime \prime} e d i n e n i c$ which literally translates as "combine," but it is traditionally translated as "organization," despite the efforts of those such as Quigley. The use of "organization" is a harmless tradition, but the use by some authors of the term "enterprise" is not so harmless. These are not enterprises (predpriiatiia); indeed, there is some discussion now in the USSR concerning an administrative reform which would change the powers of FTO's and turn them into enterprises (see Gruzinov, Upravlenic vneshnei torgovlei, p. 27).

15. Berman and Bustin, "The Soviet System of Foreign Trade," p. 1006, state that in 1974 there were sixty-one FTO's, and two Foreign Trade Offices (kontory), of which at least eighteen were under other ministries and committees. The State Committee for Foreign Economic Relations, for example, which is involved in major projects in lessdeveloped countries, has six FTO's under its jurisdiction; and the Ministry of the Maritime Fleet has several FTO's under its jurisdiction which handle such matters as servicing ships and handling port formalities (Quigley, The Soviet Foreign Trade Monopoly, p. 108). 
trade, and each is given a monopoly over a certain class of products for export and/or import. Domestic enterprises and combines, both under the control of domestic ministries, have no rights to export or import directly. Instead they must deal through Gossnab, and it in turn with an FTO and even then only with the explicit permission of the supervising ministry and, ultimately, with the approval of the Council of Ministers.

How are import decisions made, and what variables influence these decisions? Although the discussion will concern imports, much of what is said also applies to exports. Only the annual planning process for imports requires analysis because annual plans are definitive in determining the structure of imports. Although "the" foreign trade plan in the USSR actually involves several plans, the concern here is primarily with the plans for imports by countries, and for supplying imported goods to domestic enterprises. ${ }^{\mathbf{1 6}}$

One of the difficulties in understanding foreign trade decisions in the USSR is that unlike market economies there is no easily identifiable organization which de facto makes the major decisions on imports. The USSR itself is much like a large firm, and import decisions (purchasing decisions in the firm) to some extent involve the entire "firm." Also, like other firms, outsiders only have imperfect information on the decision process, information based primarily on descriptions of the formal, rather than the actual, process. Consequently, in attempting to ascertain what component parts of the "firm" are relatively more influential concerning imports, one must construct hypotheses based on incomplete descriptions and on guesses about missing information.

Domestic enterprises and combines in the USSR draw up proposals for imports which are submitted to the planning-economic administrations of the ministries; the ministries review these proposals and send them to Gosplan, which will eventually approve them with modifications. ${ }^{17}$ The FTO's also construct proposals on imports, ostensibly with no help from domestic enterprises, which are submitted to one of the three administrations on imports. These administrations in turn send proposals to the Planning-Economic Administration, which is charged with coordinating the planning process for the Ministry of Foreign Trade. The Planning-Economic Administration consults the geographic administrations (which are mainly concerned with trade agreements with countries under their competence) and the other functional administrations (for example, the Administration for Currency) in making a final draft of the plan. The plan, after moving through the hierarchy of the Ministry, is then submitted to Gosplan.

Gosplan, the Council of Ministers, and ultimately the Politburo are the institutions where import proposals are coordinated and reconciled. Details are unknown at this point, but presumably there is a good deal of infighting among domestic ministries for import allocations, and one would expect the Ministry of Foreign Trade to fight battles in areas of its own expertise: concerning which imports are possible, advisable, and so forth. The outcome is a very detailed

16. There are two plans for the export and for the import of goods by country; two for the supply of goods for export and the supply of imported goods to the domestic economy; a currency plan; a plan for the transportation of goods; and a financial plan for each FTO (see Quigley, The Soviet Foreign Trade Monopoly, p. 128).

17. Unless otherwise indicated, statements concerning the formal structure of the planning process are taken from Quigley, The Soviet Foreign Trade Monopoly, chapters 5 and 6. 
plan which, after approval by the Politburo and the Council of Ministers, is sent to the Supreme Soviet where it becomes law. This particular law is also a state secret; public sources have never revealed this law, currently or retroactively. The law incorporates a detailed breakdown of imports by country and by commodity, with specifications on types of products each enterprise may receive. The administrative and legal process by which firms request and eventually receive the products to which they are entitled according to the plan also deals with details such as the nature of the product and delivery time. Much of that process is not germane to this paper but there are several interesting points which bear on the meaning of MFN status in an Eastern economy.

The actual import plan is sent by the Council of Ministers to the Ministry of Foreign Trade as a planning assignment which the Ministry then passes on to the appropriate FTO and usually to Gossnab, which in turn passes the plan on to its supply agencies specializing in the distribution of wholesale products within the USSR. Each of these agencies negotiates an "import commission" with the appropriate FTO in which they agree on the specific product, delivery dates, and shipping. The FTO may then contact potential foreign suppliers. Before the actual import is made, however, the FTO will need to request an import license from the Ministry. In the process of considering the license application, the Ministry takes into consideration whether the product is in the import plan, whether it conforms to a trade agreement with the country in question (if there is such an agreement), the status of the trade balance with that country, and the state of political relations with that country. Presumably most of these decisions involve mainly the geographic administrations.

When the domestic enterprise finally receives its import, it is usually through an agency of Gossnab, from which it receives all other goods also. Moreover, the enterprise pays either the domestic wholesale price for a similar commodity produced in the USSR or a synthetic price designed to estimate what the domestic wholesale price would be for imports which do not have close counterparts in the USSR. This means that the domestic enterprise in the USSR does not deal directly with the FTO and certainly not with the foreign producer. Moreover, it does not know the foreign trade price for the product.

It seems reasonable to hypothesize that the three major decisions concerning imports-concerning level, commodity composition, and geographic structureare nade in different parts of the hierarchy in an Eastern economy (or in the USSR). The decision on import level is essentially made jointly by Gosplan. the Council of Ministers, and the Politburo, when they agree to accept or reject proposals from ministries concerning imports: the Ministry of Foreign Trade probably plays chiefly an informational role in stating the balance of trade implications, treaty implications, and so forth for various proposals. Decisions on the commodity structure of trade originate principally in the enterprises and the ministries, because it is there, and not in the higher administrative levels, that specific import needs originate. Of course Gosplan, the Council of Ministers, and the. Politburo, in decisions on the allocation of import funds among ministries and decisions on major investment projects, indirectly influence the structure of trade; but the major influence lies with ministries and enterprises. In both of these decision-making processes the ultimate power resides in Gosplan, the Council of Ministers, and the Politburo. In the case of product composition, one suspects that these organs play a direct role in certain major decisions (such as those 
concerning the Kama River truck plant). But on the myriad of other decisions concerning product composition the ministries probably have the power to decide subject to veto.

This kind of duality would also seem to exist in the determination of the geographic composition of trade; and here it is necessary to be more specific since this decision is of direct concern for MFN treatment. On major questions -for example, concerning how political relations will affect trade-the Politburo and the Council of Ministers probably send direct instructions to the Ministry. ${ }^{18}$ The vast majority of decisions on the geographical composition of imports, however, are not so dramatic; rather they involve hundreds of thousands of small decisions on where to purchase products specified in the import plan in cases where firms in more than one country offer a roughly comparable product. These decisions obviously cannot regularly be handled by the highest levels of the bureaucracy itself. Thus it would seem that the geographic administrations, the Planning-Economic Administration, and probably the Currency Administration play crucial roles, for they respectively concern themselves with trade balances and product compositions for particular countries, with the overall plan, and with the overall trade balance by currency areas. If there is to be discrimination on a regular basis in the choice of sources for products imported into the USSR, then aside from the few major and visible decisions which come down from the Council of Ministers, this discrimination will originate in the center of the Ministry of Foreign Trade, above the level of the FTO's and below the. level of the minister and his collegium. ${ }^{19}$

Defining and implementing MFN status in Eastern economies means specifying modifications in the import planning process itself. The two key issues here are trade agreements, which are made by the Administration of Treaties and Legal Matters and administered by the geographic administrations, and the goal of zero bilateral trade balances, which is enforced by the geographic administrations. Consequently, specifying MFN status means proposing a dramatic reduction in the role of geographic administrations in the planning process.

The preference for bilateral balance of trade is not confined to the Eastern side alone; many Western governments complain to trade partners with which they have large deficits. But the tendency toward bilateralism may be stronger

18. In fact, a set of instructions to the Ministry of Foreign Trade from the Council of Ministers has been in force since the late 1920s. The instructions allow the Ministry to curtail trade with countries which do not have diplomatic relations with the USSR, or which discriminate against USSR products (see Harold J. Berman, "The Legal Framework of Trade Between Planned and Market Economies: The Soviet-American Example," Law and Contemporary Problems, 24 [1959]: 502-3). And recently, a department head in the Treaty and Legal Administration of the Ministry of Foreign Trade made a point of confirming that those instructions are still in force (see V. G. Smirnov, "The System Regulating Exports and Imports in the USSR," in American-Soviet Trade: A Joint Seminar on the Organizational and Legal Aspects, Moscow, December 1975 [Washington, D.C.: U.S. Department of Commerce, Bureau of East-West Trade, 1976]).

19. There is no reason for the FTO's themselves to discriminate. If they are not constrained in their choice of country or area for imports, their plan indicators can only improve by purchasing commodities from the cheapest sources. It is their plans, including import quotas for countries and products, which restrict them. And those plans come from the Ministry, in particular from the administrations. 
in the East in that there are specific instructions to geographic administrations to achieve a zero balance where possible (after allowing for credits or repayments). MFN status cannot exist where exports must equal imports in each bilateral trade flow at a fixed exchange rate. Only in very special circumstances would exports equal imports under MFN relations between an Eastern economy and a Western economy. Thus, if both sides are serious in granting MFN status, both must give up any specification concerning their trade balance; otherwise they have set one too many variables for it to exist.

Bilateral trade agreements are a complex issue about which Eastern governments have a right to be sensitive. Ministries of foreign trade play a role in foreign trade decisions which mixes the functions of the government and the firm in market economies. In some situations they act as a government entity negotiating inter-nation trade agreements. At other times they act like corporate purchasing divisions, agreeing to buy so many units of various products over a certain period of time, with specific negotiations on specific products to be concluded by the FTO's (where the FTO's will probably seek competitive bids within the given market economy). Because purchasing departments in Western firms frequently make long-term commitments for purchases of certain products (particularly primary products and fuels), it would be unfair to try to prevent the ministries of foreign trade from doing the same. On the other hand, these long-term contracts are typically made in Western economies on a lowest bid basis and it is the essence of MFN agreements that some system of that sort be used by ministries of foreign trade.

In light of these considerations, a feasible approach to implementing MFN treatment in the Eastern economy might use the old British formula that "commercial considerations" should be the only considerations that motivate decisions on Eastern imports, ${ }^{20}$ but it should be more specific in applying what is known about planning in Eastern economies to stipulate the following: (1) no import contracts shall be signed save on a competitive bid basis where firms in all countries receiving MFN treatment have the right to bid, and where the lowest bid is accepted; (2) the average length of contracts by product group, signed by the Ministry of Foreign Trade, shall not substantially exceed that typical for contracts in the respective product groups in trade among market economies ;21 (3) geographic administrations in the Ministry of Foreign Trade should either be abolished or relegated to a nonoperational role in the annual planning process, and no other institutions should be developed to inject a priori geographic considerations into the determination of imports; and (4) individual bilateral trade balances shall not be a consideration in the planning process. Should Eastern 58-59.

20. Domke and Hazard, "State Trading and the Most-Favored-Nation Clause," pp.

21. An agreement to buy a product over a fixed period of time is also an announcement that competitive bids will not be entertained during that period. Such agreements are typical in private contracts between firms in Western economies, and I am assuming without any empirical verification whatsoever that norms have evolved in the world economy concerning the length of time, typically stipulated in the agreements for specific products, that the bidding process is suspended. This second provision seeks to ensure that Eastern economies, particularly in their mutual trade, do not enter into agreements for specific products which cover abnormally long time periods. If they were allowed to do so, the first provision on competitive bidding would lose a great deal of its force. 
governments agree to such stipulations one could still not be sure that they. were indeed granting MFN treatment. It is much like an arms control problem, but worse, because satellites cannot take pictures of decision processes the way they can of missile silos. Nevertheless, it would be an important step toward ensuring that Eastern countries are giving genuine MFN treatment to imports.

Eastern governments would be likely to regard such recommendations as an unacceptable interference in the system they use to allocate resources, and it is undeniably interference. But when Eastern governments ask for MFN treatment they ask that Western governments refrain from using the instruments at their disposal (primarily prices, but also quotas) to discriminate against Eastern goods. When Western governments ask for MFN treatment, they ask that Eastern governments refrain from using the instruments at their disposal (trade agreements and planning) to discriminate against Western goods. There is no actual asymmetry in these requests.

The likelihood that Eastern governments will refuse such a solution as interference in their internal economic affairs is, however, just the position around which a case can be built for unilateral import quotas in reciprocation for $\mathrm{MFN}$ treatment by Western economies. It is true that MFN treatment does not carry with it, and should not carry with it, a guarantee concerning its impact on trade flows. In fact this is one argument Eastern negotiators use against the proposition that quotas are an appropriate concession for MFN treatment. ${ }^{22}$ But if Eastern governments refuse to commit themselves to visible measures which would unquestionably signal a move toward genuine MFN treatment, then they should be asked to undertake visible measures concerning the results which their granting of MFN status might yield. If they are not willing to give up some of the visible institutional instruments of geographical discrimination in imports, which would in turn change the geographical composition of trade, then they should be required to give up some of the results. The second solution has the advantage for them that they can retain the trade planning system as is; they merely run the new quotas through the geographic administrations. For Western economies the end result is what they could expect to obtain in any event under MFN treatment.

The difficult question here is just what level of imports to ask for from the various Eastern governments. This is not an easy question to answer, and it appears to have received little attention in the past. Most likely the 7 percent per annum import growth figure in the Poland-GATT negotiations originated with Poland. Moreover, the earlier figures in other agreements also may have come from the Eastern negotiators themselves. This is one sensible approach which it may pay to follow. Western economy negotiators could ask for "bids" on how much Eastern imports would rise if they were to receive MFN treatment; then, if a satisfactory bid would be found, the agreement would be signed. Eastern negotiators presumably would offer imports on the low side of what they consider a reasonable estimate of the additional exports MFN treatment would bring. Western negotiators also presumably have estimates of how much

22. For examples, see János Nyerges, "Hungary's Accession to GATT," New Hungarian Quarterly, 17 (Summer 1976): 133-42; and L. Sabel'nikov, "Neobkhodimoe uslovie mezhdunarodnoi torgovli" [The Necessary Conditions of International Trade], Mirovaia ekonomika i mezhdunarodnye otnosheniia, May 1976, p. 112. 
imports will rise from the centrally planned economy and evaluate their import proposals accordingly. Of course, as Domke and Hazard point out, this type of agreement discriminates in order not to discriminate, but that may be better than institutional purity with less trade. In any event, if the agreement is multilateral, this is not such a serious problem. ${ }^{23}$

Western negotiators might take a more active role by generating their own estimates of what bilateral trade flows would be if both sides granted MFN treatment. Economists have found some fairly simple statistical models which estimate with acceptable accuracy how much trade would typically occur between two countries of a given population and level of economic development. ${ }^{24} \mathrm{~A}$ model of this nature could be used to predict what the level of total bilateral trade would be if trade were conducted according to norms typical in the rest of the world, taking account of the typical amount of discrimination against trade in general, and the typical impact of economic unions. ${ }^{25}$ There are also somewhat more sophisticated models available which would provide alternative estimates for the same variables, such as the equal-price market share models which Brada and Wipf have applied to analyses of CMEA trade with Western countries. ${ }^{26}$ The particular advantage of this model over the gravity model is that it allows one to see if price for each product group which a particular Western economy exports to an Eastern economy is the only consideration determining that country's export share on the Eastern market. The gravity model could only spot major deviations of total trade from world norms; the equalprice market share model can identify deviations in total and by product group. The major disadvantage of this model is that it requires a very fine breakdown of data, typicaliy not available from published sources.

The details of these models will not be discussed here. The only point is to advocate economic modeling as an approach in the negotiating process. As available models and data are crude, the results could serve only as a supplement in traditional negotiations.

In summary, the practice, which some trade agreements have followed, of requiring quantitative agreements from Eastern governments in exchange for MFN treatment seems a sensible one. It is not a necessary one, but it seems a feasible second-best path if Eastern governments refuse the alternative of moderate institutional reform. However, if quotas are to become a means for Eastern countries to reciprocate MFN treatment, economists should be part of the team which negotiates what the quotas will be. The negotiators will be negotiating not on the institutions which decide on trade-something about which lawyers are much better qualified to advise than economists-but about the results which would accrue if those institutions were changed, which is where the economist has a comparative advantage.

23. Domke and Hazard, "State Trading and the Most-Favored-Nation Clause," p. 65.

24. For an application of such a model to the CMEA countries see Edward A. Hewett, "A Gravity Model of CMEA Trade," in Josef C. Brada, ed., Quantitative and Analytical Studies in East-West Economic Relations (Bloomington, 1976), pp. 1-16.

25. The model automatically takes care of the first, the second is easy to incorporate.

26. J. C. Brada and Larry J. Wipf, "The Export Performance of East European Nations on Western Markets," Weltwirtschaftliches Archiv, March 1975. 
There is much that has been left out of this paper, and several problems which deserve more attention are discussed below.

First, the focus has been on MFN treatment for imports, primarily through tariffs, and no mention has been made of export discrimination. No doubt discriminatory barriers to exports will also be a subject of discussions, as they should be, in negotiations on mutual reduction of trade barriers. That, however, is a somewhat separate subject. It is true that, in the case of the United States for example, there are still special politically motivated controls on exports to the CMEA countries, and the CMEA countries would naturally like to have them removed. But the CMEA countries also have special politically motivated controls on their exports in which, for example, Eastern Europe receives first call (up to a point) on many primary products. The controls have a different purpose: the Soviets discriminate in favor of a partner and if they did not do it there might be political problems in Eastern Europe; the United States discriminates against the CMEA countries, and no political repercussions with our trade partners would accompany an almost complete abolition on those export controls. The point is, though, that both sides currently apply export controls.

A second issue involves the plausibility of asking any Eastern government for quotas in exchange for MFN treatment. Granting MFN status in tariffs may only have a minor impact, if any at all, on imports from the centrally planned economy which receives MFN treatment; on the other hand, the removal of discriminatory quotas does seem to have some positive impact. ${ }^{27}$ Brada and Wipf have suggested that market efforts by the CMEA countries may have much more to do with their market share than MFN status. ${ }^{28}$

If MFN treatment would have little effect on the exports from Eastern countries, other than what they would achieve from increasing their marketing efforts, then the Eastern government will naturally not be willing to give up much in return. Ironically, in order to reduce substantially Eastern discrimination against a Western economy, that Western economy should be discriminating as heavily as possible against its negotiating partner before it enters the negotiations. ${ }^{20}$

The issue of dumping also plays a major role in most East-West negotiations, and in fact fear of dumping is apparently one reason Western governments continue to discriminate against Eastern goods. Nevertheless, dumping involves issues separate from what has been discussed in that it is not related to how Eastern governments discriminate against Western goods. Insofar as Western governments hold on to discriminatory measures against Eastern goods because of their fear of dumping, however, the issue will be an important component of the negotiations concerning the granting of MFN status by Western governments.

27. For a review of the recent literature on this, see Thomas A. Wolf, "The Impact of Formal Western Restraints on East-West Trade: An Assessment of Existing Quantitative Research," in John P. Hardt, ed., Tariff, Legal and Credit Constraints on East-West Commercial Relations (Ottawa, 1975), pp. 27-55.

28. J. C. Brada and Larry Wipf, "Romanian Export Performance in Western Markets: An International Comparison," in Brada, Quantitative and Analytical Studies, pp. 37-50.

29. Andrew Ian Douglass suggests that this may be one of the reasons that the Contracting Parties in GATT have been reluctant to reduce their trade barriers. High trade barriers give them extra bargaining power for concessions (Douglass, "East-West Trade," p. 760). 
The special case of intra-CMEA trade must also be considered. In negotiations between a group of Western economies and an individual Eastern economy, or a group of Eastern economies, the special relationship of these countries to each other through the CMEA will surely become a key point of contention. There is little doubt that intra-CMEA trade receives special protection by each of the CMEA countries, "special" even in comparison to protection typically accorded intramember trade in a customs union. ${ }^{30}$ But the prospects for changing that discrimination are linked to some very complex economic and political issues, of which the most important are the following: (1) the level, structure, and terms of trade are all part of Soviet foreign policy, and dramatic changes in those are in fact changes in Soviet foreign policy; (2) the Transferable Ruble, used as a denominator for CMEA trade, is inconvertible; hence no CMEA country could, under the present institutional arrangements, finance a deficit with Western countries by a surplus earned within the CMEA; and (3) all CMEA countries have developed a great deal of their productive capacity for the protected CMEA market, leaving them in a difficult situation. Even if they were to try to reduce protection for CMEA trade, the resulting freed capacity for manufactured products could not easily produce products competitive on Western markets.

The first point involves some very important foreign policy objectives for the USSR, and there is no prospect that the Soviet Union will significantly change these objectives for the relatively miniscule benefits which might flow from MFN status. But this issue may take care of itself in other ways. As the Soviets have become increasingly aware of the very high costs of their preferences for East European goods, they have begun to seek ways to change the structure of trade.

Also, the problem of convertibility is not going to be solved very soon, and certainly not through negotiations. I subscribe to Franklyn Holzman's argument that inconvertibility in the CMEA is a necessary symptom of central planning, and therefore one cannot advocate the abolition of the former without at the same time contemplating doing away with the latter. Again, such choices are not stimulated by offering MFN treatment. ${ }^{31}$

These two points aside, surely part of the constraining forces behind the geographic structure of CMEA trade lies not in politics nor in systems, but in the factors listed in point three, that is, in the inherited constraints of past decisions. Thus, in many cases, one can see that the constraints on East European imports from the West stem from their limited capacity to export to the West, something which can only slowly change. In setting import quotas for the CMEA countries which receive MFN treatment it would seem fair to recognize this state of affairs through the requirement that they be expected on the margin (that is, in the increase in their total trade) to allocate trade geographically, as a country would which was giving MFN status globally.

30. In "A Gravity Model of CMEA Trade," I estimate that the level of intra-CMEA trade is three to four times higher than it would be if the CMEA protected trade as much as the EEC or EFTA typically do.

31. Franklyn Holzman, "CMEA's Hard-Currency Deficits and Ruble Convertibility," paper presented at the International Economics Association Meetings in Dresden, July 1976. 
In the long run MFN treatment may not turn out to be the major issue at all. If the CMEA countries' discrimination in favor of themselves, and their discrimination against all foreign producers in favor of domestic producers are considered as the major forces depressing East-West trade, then the latter is probably the more important source of downward pressure on all trade, including East-West trade. Thus it may well be that some day in the future Western governments will have to sit down with Eastern governments not to negotiate MFN treatment, but to negotiate a reduction in the very high barriers against all trade in Eastern countries. 